\title{
RUPIOID HISTOPLASMOSIS: FIRST CASE REPORTED IN AN AIDS PATIENT IN ARGENTINA
}

\author{
Marcelo CORTI(1), María F. VILLAFAÑE(1), Omar PALMIERI(1) \& Ricardo NEGRONI(2)
}

\begin{abstract}
SUMMARY
Disseminated histoplasmosis is a relatively common AIDS-defining illness, occurring in almost $4 \%$ of patients living in endemic areas and it may be the first clinical expression of the HIV infection. A broad spectrum of clinical skin lesions associated with Histoplasma capsulatum infection have been described in AIDS patients, such as erythematous macules, papules, nodules, and pustules. Herpetic, acneiform, erythema multiforme-like, molluscum contagiosum-like, vasculitic, and exfoliative forms have also been reported. To our knowledge, this is the first case of disseminated histoplasmosis in an AIDS patient presented as a rupioid eruption.
\end{abstract}

KEYWORDS: Histoplasma capsulatum; Rupioid lesions; HIV; AIDS.

\section{INTRODUCTION}

Histoplasmosis is a systemic mycosis, endemic in areas of subtropical and tropical climate. It is prevalent in North, Central and South America as well as in wide areas of Africa and Asia.

Histoplasma capsulatum is a dimorphic fungus that can cause a disseminated and severe disease in patients with impairment of cell-mediated immunity. Disseminated histoplasmosis is a frequent opportunistic infection in AIDS patients in Argentina, with an incidence around $4 \%$ of the patients who required admission to the hospitals ${ }^{3}$.

Here, we present a case of disseminated histoplasmosis with a rare crusty cutaneous lesion considered as rupioid histoplasmosis.

\section{CASE REPORT}

A 37 year-old homosexual man, HIV seropositive since 2003, with multiple withdrawal of highly active antiretroviral therapy (HAART) and a previous diagnosis of Kaposi's sarcoma presented with a history of fever, productive cough and weight loss of 15 days duration. Physical examination revealed a temperature of $38^{\circ} \mathrm{C}$, cachectic status, dyspnea, tachycardia, tachypnea, disseminated bilateral crackles and hepatosplenomegaly.

Cutaneous examination showed few skin macular and nodular lesions of Kaposi's sarcoma and multiple and disseminated papules and papulonecrotic lesions predominant on the thorax and the limbs. On the face, the physical examination revealed multiple crusted lesions covered with dirty looking, adherent and heaped-up crusts on the cheeks, the wings of the nose and around a great ulceration located at the central area of the forehead (Fig. 1). Additionally, he had an ulceration on the hard palate.

Laboratory tests showed hematocrit $28 \%$; erythrocyte sedimentation rate (ESR) $41 \mathrm{~mm} / 1^{\text {st }}$ hour, white cell count (WBC) 2300/ $\mathrm{mm}^{3}$; platelets
$112000 / \mathrm{mm}^{3}$; and a discrete elevation of alkaline phosphatase. Renal function, plasmatic glucose, $\mathrm{LDH}$ and urine examination were normal. VDRL was non reactive. The CD4 T cell count was 7 cell/ $\mu \mathrm{L}(3 \%)$.

A chest radiography showed a bilateral interstitial infiltrate extending from the vertices to the bases of the lungs (Fig. 2). Sputum examination was negative for bacteria, mycobacteria and fungus. Abdominal ultrasonography confirmed the existence of hepatomegaly and splenomegaly with multiple hypoechoic lesions

The histopathology of skin biopsy smears from the forehead lesions showed several intracellular and extracellular oval structures stained with hematoxylin-eosin in the superficial dermis (representing Histoplasma capsulatum organisms). The fungal organisms were also demonstrated in the dermis with Periodic Acid-Schiff (PAS) and Grocott's Methenamine Silver stains (Fig. 3). Blood culture with a lysis centrifugation technique was positive for $H$. capsulatum.

A diagnosis of disseminated histoplasmosis was made on the basis of the cutaneous biopsy findings and the blood cultures. Itraconazole therapy was initiated; unfortunately the patient did not experience clinical improvement and died.

\section{DISCUSSION}

Histoplasma capsulatum is a dimorphic mould found mainly in moist soil. In HIV infected patients that have less than $100 \mathrm{CD} 4 \mathrm{~T}$ cells $/ \mu \mathrm{L}$, histoplasmosis may be a life-threatening and disseminated disease with mucocutaneous, pulmonary, bone marrow and liver involvement, as we could see in our patient ${ }^{2}$.

In endemic areas, histoplasmosis is frequently the first opportunistic infection in HIV infected patients with an incidence ranged from 5\% to $20 \%{ }^{6}$. In South America, more than $80 \%$ of the patients have skin lesions 


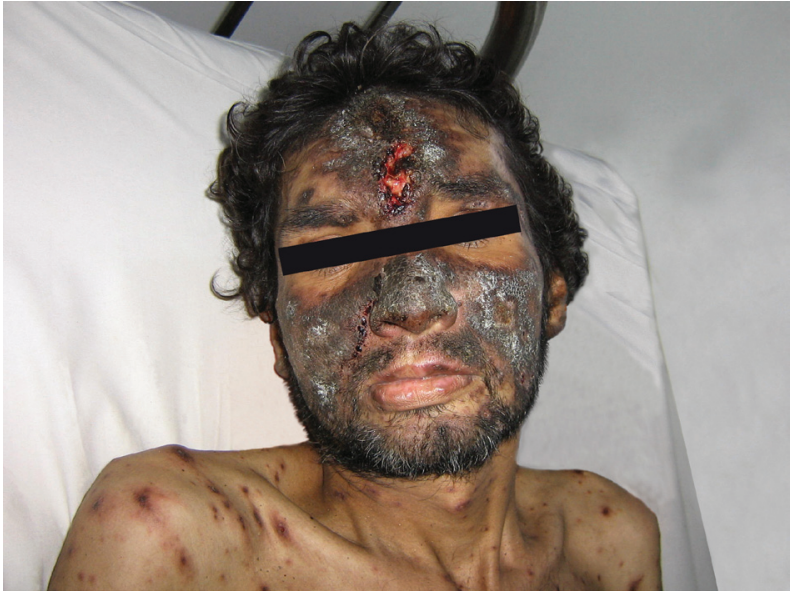

Fig. 1 - Extended rupioid lesions over the face with a deep ulceration in the middle of the frontal area in a case of disseminated histoplasmosis.

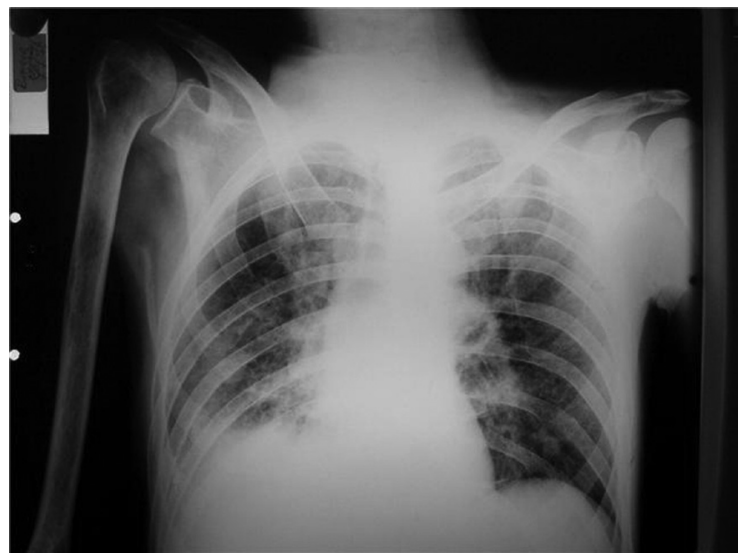

Fig. 2 - Chest radiograph showed the bilateral infiltrate due to Histoplasma capsulatum.

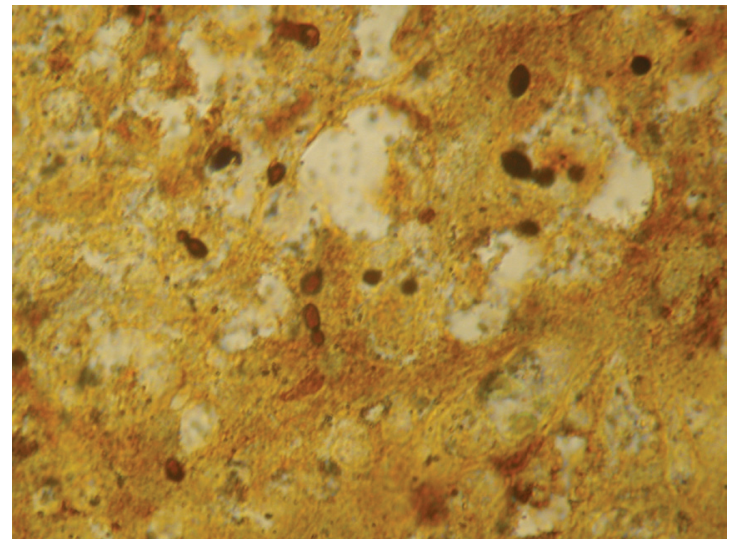

Fig. 3 - Histopathology of skin biopsy with Grocott's stain showing fungal microorganisms compatible with Histoplasma capsulatum.

which manifest as a diffuse maculopapular eruption, folyculitis and papulonecrotic lesions with an acneiform aspect and indurate perianal ulcers. The localization of the skin lesions in these patients is mainly on the face, neck and thorax and less often on the limbs ${ }^{4}$. In addition to skin lesions, mucosal lesions (ulcers) were present in early $25 \%$ of the individuals.
Rupioid skin lesions have been generally associated with a rare form of malignant secondary syphilis ${ }^{1}$, and are also usually seen in patients with psoriasis ${ }^{5}$.

The face is the common site of rupioid lesions. The term rupioid refers to a disseminated extended pustular, hyperkeratotic and papular lesion which progresses rapidly to a destructive and well delimitated lesion with central necrosis. Besides, this ulcerative lesion is rounded by a large number of adherent crusts resembling an "oyster shell"' Recently, BHAGWAT et al. ${ }^{l}$ published a case of rupioid lesions as a cutaneous manifestation of secondary syphilis in a HIV patient ${ }^{6}$.

To our knowledge, this is the first case of disseminated histoplasmosis in an AIDS patient presented as a rupioid eruption. Due to the asymptomatic nature of Histoplasma capsulatum cutaneous lesions in AIDS patients and their extraordinary variable aspect, a great diagnosis suspicion is required, therefore we emphasize the need to scrape and biopsy all suspected lesions in this kind of patient. Special stains must be applied in all mucocutaneous biopsy specimens from HIV-seropositive patients in whom the possibilities of disseminated histoplasmosis is being considered.

\section{RESUMO}

\section{Histoplasmose rupioide: primeiro caso relatado em um paciente com AIDS na Argentina}

A histoplasmose disseminada é uma das doenças associadas à AIDS e relativamente comum, ocorrendo em quase $4 \%$ dos pacientes que vivem em áreas endêmicas e pode ser a primeira expressão clínica da infecção pelo HIV. Amplo espectro de lesões de pele associadas com a infecção pelo Histoplasma capsulatum têm sido descritas nos pacientes com AIDS, tais como máculas eritematosas, pápulas, nódulos e pústulas. Foram também relatadas lesões herpéticas, acneiformes, similares ao eritema multiforme, similares ao molusco contagioso, vasculíticas e esfoliativas. Em nosso conhecimento este é o primeiro caso de histoplamose disseminada em paciente com AIDS que se apresenta como erupção de aspecto rupióide.

\section{REFERENCES}

1. Bhagwat PV, Tophakhane RS, Rathod RM, Shashikumar BM, Naidu V. Rupioid syphilis in a HIV patient. Indian J Dermatol Venereol Leprol. 2009;75:201-2.

2. Cohen PR, Groosman ME, Silvers DN. Disseminated histoplasmosis and human immunodeficiency virus infection. Int J Dermatol. 1991;30:614-22.

3. Corti ME, Cendoya C, Soto I, Esquivel P, Trione N, Villafañe MF, et al. Disseminated histoplasmosis and AIDS: clinical aspects and diagnostic methods for early detection. AIDS Patient Care STDS. 2000;14:149-54.

4. Gutierrez ME, Canton A, Sosa N, Puga E, Talavera L. Disseminated histoplasmosis in patients with AIDS in Panama: a review of 104 cases. Clin Infect Dis, 2005;40:1199202.

5. Murakami T, Ohtsuki M, Nakagawa H. Rupioid psoriasis with arthropathy. Clin Exp Dermatol. 2000;25:409-12.

6. Wheat LJ, Kauffman CA. Histoplasmosis. Infect Dis Clin North Am. 2003;17:1-19. 